\title{
Training Needs of Governmental Schools' Principals Hosting Kindergartens Classes: The Case for Jordan
}

\author{
Mamdouh M. Ashraah ${ }^{1}$, Ali M. Al-Olaimat ${ }^{2} \&$ Hanan M. Takash ${ }^{3}$ \\ ${ }^{1}$ Faculty of Educational Sciences, the Hashemite University, Zarqa, Jordan \\ ${ }^{2}$ Early Childhood, Faculty of Education, Isra University, Jordan \\ ${ }^{3}$ Queen Rania Faculty for Childhood, Special Education, the Hashemite University, Jordan \\ Correspondence: Mamdouh M. Ashraah, Faculty of Educational Sciences, the Hashemite University, Zarqa, \\ Jordan. E-mail: drashraah@yahoo.com
}

Received: February 19, 2015 Accepted: March 27, 2015 Online Published: July 28, 2015

doi:10.5539/ies.v8n8p129

URL: http://dx.doi.org/10.5539/ies.v8n8p129

\begin{abstract}
This study aimed at identifying the training needs of governmental schools' principals with kindergarten classes. The sample of the study consisted of a random sample of (62) female principal. The instrument of the study was developed by the researchers and included 60 items distributed on four domains (planning, organizing, guidance, and assessment). The results of this study indicated that governmental school principals needed training in the areas of planning, organization, guidance and assessment. The results also indicated that academic qualification and years of experience did not have any statistically significant effect on domains of the study. The study provided a number of recommendations such as designing training courses for governmental schools' principals, increasing the number of training courses and programs.
\end{abstract}

Keywords: government schools, Jordan, kindergarten, school principals, training needs

\section{Introduction and Theoretical Framework}

The world today is experiencing major changes in various aspects of life including information technology, social, economic, and cultural developments, and methods of doing things especially in the school system. In response to these changes, many schools are adding kindergartens as part of their educational reform. This addition to schools has needs related to the curriculum, the textbooks, the instructional materials, and the school facilities. However, the presence of a capable principal who is able to manage these variables properly is regarded as the most important variable in the educational process. This demand paying close attention to the training needs of principals to better equip them with the needed skills to manage schools with kindergartens successfully (UNESC, 1996).

It is indicated that having capable principals with high management skills is still facing shortages in the educational system. This could be attributed to the fact that training courses provided by the ministry of education are not planned well enough to meet the actual training needs of principals (Hanna, 2003). Having skillful principals within school administration is one of the most important factors that can influence instructors and students behavior. Also, it is well-articulated that poor school management may strongly impact the culture of teaching and learning in schools (Ngidi \& Qwabe, 2006). This can be accomplished by having principals who set the right example and resemble a role model for others, which in turn encourage commitment of instructors and students to their roles in the school (Al-Mekhlafi, 1997).

In response to the dynamic changes in school reforms, the school administration especially principals should succeed with changes and transformations within their schools (Mestry \& Singh, 2007). The school administration have multiple duties and functions and it is not limited only to the managerial aspect but also to other functions such as supervising the educational process, diagnosing its weaknesses and strengths, and guiding teachers (Margaret, 1998; Mousa, 1994). Based on the importance of these roles, there is an urgent need to design training programs based on actual needs of school principals to conduct their roles successfully (Carpenter, 2001). Training occupies an essential place among the managerial activities that aim at increasing competency and improving work styles. Recently, training has become one of the most important means in education because it doesn't only introduce knowledge, but it goes beyond for changing convictions and 
attitudes and acquiring innovative skills and practical experiences (Abdeen, 2001; Al-Ta'any, 2007).

Training is very important for the individual and institution where Cheelana states that good training with good organization is essential for improving and developing the efficacy of any profession (Musatfa, 2010). However, it is more necessary and important for educators and workers in the teaching field because education occupies a strategic place within the mission of human development (Falouqi, 2003). Mathibe (2007) mentioned that poor results in schools can be attributed to lack of training of school principals to deal with transformations which necessitates the continuous professional development of principals. Training can develop principal's knowledge, skills, and abilities; raising principals' desire for change, and improve overall quality (Al-Ezawi, 2006; Qanadeli, 2003).

Based on that, a thorough review of the literature was conducted to determine the training needs that are needed for school principals to better achieve their jobs. These needs were centered on four primary areas including planning, organizing, assessment, and guidance. Planning is considered the foundation for accomplishing the goals of education in society (Kashwa, 1999). Principals need to be able to design timetables that are flexible for school work. Also, they should be aware of school capabilities, local community facilities, and ways for mutual cooperation (Rafa, 1993). In addition, principals have the responsibility of formulating committees and supervising their duties around the year (Nashwan, 1991). Therefore, developing school's plan is considered the ultimate goal of the planning role for the secondary school principal (Lauder, 2000).

With regard to the organizing dimension, principals should be able to divide distribute work duties among instructors and workers, define the authorities and specializations of school workers, and linking these workers through a network of relationships and communications that guarantees the normal and competent procession of school work and procedures (Fahmi, 1993; Abu-Sheikha, 1998). These duties can guarantee the quality and accuracy of the school organization (Diab, 2001). The assessment domain is equally important because it allows principals to evaluate the results of their planned actions and the achievement of the educational standards set in the planning phase. This allows principals to determine whether their goals have been accomplished (Al-Rawi \& Others, 2000; Barbara, 2006; Sankar, 1980). The last domain is guidance, which is represented by conducting a group of artistic activities and events that aim at developing the educational process (Al-Rawi et al., 2000). These processes include supervising instructors' professional growth, curriculum and instructional development, and academic achievement (Al-Sane, 1995).

With regard to previous studies concerning training needs of school principals, a study by Al-Zmeily (2005), aimed at determining the role of the training workshops in improving the performance of governmental schools' principals in Ghaza. The most important results this study came up with were that the training workshops succeeded in helping the principals greatly acquire the managerial and technical skills of their jobs. Also, the results revealed that good preparation like planning for the training courses improved new principals' performance. Another study by Al-Ghamedy (2004) found that principals are in need for managerial and technical training within Al-Baha educational area. Hanna's (2003) study aimed at identifying the training demands of Jordanian kindergartens' principals. The results of the study indicated that principals need training in the areas of skills for organizing and developing the kindergarten's educational environment, communication and relation with the local community, planning and managing skills, and assessment skills.

Al-Ajaj's study (2001) aimed at identifying the training needs of the governmental schools' principals in the governorate of Al-Qrayat. The results of the study showed that principals have training needs in the areas of educational techniques, developing the studying curriculum, and the instructional process. Al-Shmeiry's study (1995) emphasized the need for training in the domains of managerial executive, affairs of the instructional staff, students' affairs, improving and developing curricula, school's relation with the local community, and financial and facilities affairs. Jaradat's Study (1991) aimed at identifying the training needs among the governmental basic schools' principals in Irbid. Results revealed that the principals have high training needs for managerial skills related to managerial, instruction affairs, students' affairs, curriculum development, school's relation to the local community, and financial and facilities affairs.

In conclusion, the issue of providing school principals with the needed training in all aspects of school management to cope with the changes and transformations of the $21^{\text {st }}$ century is an urgent need not only in Jordan but also in many parts of the world including United States, United Kingdom and South Africa (Bush, Kiggundu, \& Moorosi, 2011).

\subsection{Statement of the Problem}

In a world characterized by advances in all aspects of life, the school administration should keep up with such base to be successful. In particular, school principals carry out the most weight with regard to the success of the 
educational process. It appears to be a shortage in training for secondary school principals who have kindergarten classes in their schools in Jordan. While much research has been written in western countries about the skills successful school principals, limited research has been written in the developing world (Prew, 2007). To the researchers' best knowledge; there are limited studies in Jordan that addressed specifically the training needs of the governmental schools' principals who have kindergartens within their schools. Therefore, the primary purpose of the study was to determine the training needs of governmental schools' principals who have kindergartens.

\subsection{Research Questions}

To achieve the primary purpose of the study, the following research objectives were formulated:

- To determine training needs of governmental schools' principals whose schools are supplemented by kindergartens based on their perceptions.

- To determine if significant differences exist in the training needs of governmental schools' principals based on the demographic variables of academic qualification, experience, and training workshops.

\subsection{Importance of the Study}

This study is beneficial for a number of stakeholders. First, the ministry of education may use the results of the study to respond to the training needs of their school principals by providing training workshops on a continuous basis. Second, training professionals may take proactive steps to improve the quality of training course provided to school principals in light of their demands. Third, schools may use the results of the study to come up with a list of training needs and send it to the training department in the ministry of education for improvement purposes. Finally, this study may be the cornerstone for other similar studies in Jordan.

\section{Methodology}

\subsection{Population and Sample}

The population of the study consisted of (127) kindergartens' female principals in Al-Mafraq educational district. A random sample of (62) female principals was chosen for the study. The sample distribution is provided in table 1.

Table 1. Sample distribution according to study's variables

\begin{tabular}{llll}
\hline Variable & Level & Number & Percentage \\
\hline \multirow{3}{*}{ Academic qualification } & B.A. & 43 & $69.4 \%$ \\
& Higher Education & 19 & $30.6 \%$ \\
& Total & 62 & $100 \%$ \\
& Less than 5 yrs. & 29 & $46.8 \%$ \\
Experience & 5-10 yrs. & 20 & $32.3 \%$ \\
& More than 10 yrs. & 13 & $21 \%$ \\
& Total & 62 & $100 \%$ \\
Training courses & Less than 3 courses & 21 & $33.5 \%$ \\
& 3-5 courses & 22 & $36.2 \%$ \\
& More than 5 courses & 19 & $31.3 \%$ \\
& Total & 62 & $100 \%$ \\
\hline
\end{tabular}

\subsection{Instrumentation}

To achieve the primary purpose of the study, the researchers developed an instrument based on a review of previous research (Al-Ghamedy, 2004; Al-Shmeiry, 1995; Azofa, 1995; Jaradat, 1991; Al-Ajaj, 2001). The instrument consisted of two parts: the first part included the study variables, and the second included items of the instrument which were (60) distributed among four domains (planning (13 items), organizing (18 items), guiding (15 items), and assessment (14 items). Responses to the items were measured on a five-point Likert-type scale (very high, high, medium, weak, absent). To ensure the validity of the instrument, items were reviewed by a 
group of experienced university professors in the areas of linguistic formulation, clarity, accuracy and the items' belonging to their domains. Changes recommended by the panel were incorporated into the instrument which was in the wording of few items. To determine the reliability of the instrument, a pilot study of (25) principals whom were excluded from the main sample of the study was utilized. The reliability coefficients were acceptable as follow: planning $(\alpha=0.93)$; organizing $(\alpha=0.84)$; guiding $(\alpha=0.95)$; and assessment $(\alpha=0.92)$. However, the overall reliability for the instrument was 0.93 .

\subsection{Data Collection and Analyses}

The instruments were distributed by the researchers to the study participants at the beginning of the first semester of the academic year (2013/2014). The participants were informed of the purpose of the study and assured them the confidentiality of responses and voluntary nature of the study. The instruments were collected during the same time of distribution. The administration and collection process took approximately 25 minutes to complete. The instruments were then entered into the SPSS statistical software. To achieve the first objective, means and standard deviations were used. To achieve the second objective, t-test and ANOVA were used.

\section{Results and Discussion}

\subsection{Results and Discussion Pertain to the First Objective}

The first objective was to determine training needs of governmental schools' principals whose schools are supplemented by kindergartens based on their perceptions. Means and standard deviations were used to answer this objective. As indicated in Table 2, the highest mean was for the planning domain, followed by organizing, guidance, and assessment respectively. It is noted that secondary school principals that host kindergartens have high training needs for all domains. To elaborate, principals have high concerns for the kids' interest and education as well as identifying their problems and finding proper solutions for them. This result agrees with the results of Azofa's (1995) study. That's of course indicates their certain need for being trained on these skills, and that they actually lack some of them. Consequently, they cannot do their duties properly which is a normal result considering the fast changes on today's world. Thus, change or renewal has become a reality and an inevitable demand, and it requires flexible and continuous training programs so as to cope with that updating within the contents, methods, aids and execution techniques. These results agree with the views of Prew (2007) who emphasized the fact that successful principals with the above mentioned skills will succeed when faced with innovation and transformation.

Table 2. Means and standard deviations for the domains of the study

\begin{tabular}{cccccc}
\hline No. & Domain & Mean & SD & Rank & Degree of Need \\
\hline 1 & Planning & 4.16 & 0.636 & First & High \\
2 & Organizing & 4.14 & 0.560 & Second & High \\
3 & Guidance & 4.07 & 0.763 & Fourth & High \\
4 & Assessment & 4.11 & 0.741 & Third & High \\
& overall & 4.07 & 0.551 & - & High \\
\hline
\end{tabular}

The data were explored further with regard to each domain separately. Table 3 shows the means and standard deviation for the 13 items of the planning domain. As shown in the table, item 1 (familiarity with making the kindergarten's semester, monthly and weekly plan); item 3 (acquaintance with sharing planning to activate the parents' collaboration in making plans), and item eleven (planning the kindergartens' activities) had the highest mean values. As well, the rest of the items also had high demands for training. These results indicate that principals greatly realize the requirements of their leading position so as to practice their professional and technical duties properly, in addition to their certain desire for advancing and developing their performance skills to satisfy these requirements which are peculiar to the kindergarten stage. 
Table 3. Means and standard deviations for the items of the planning domain

\begin{tabular}{|c|c|c|c|c|}
\hline No. & Item & $\begin{array}{l}\text { Mean } \\
*\end{array}$ & SD & $\begin{array}{l}\text { Demand } \\
\text { Degree }\end{array}$ \\
\hline 1 & $\begin{array}{l}\text { Familiarity with making the kindergarten's semester, monthly and } \\
\text { weekly plan. }\end{array}$ & 4.41 & 0.722 & Very high \\
\hline 2 & Familiarity with making the kindergarten's semester plan. & 3.99 & 0.794 & High \\
\hline 3 & $\begin{array}{l}\text { Acquaintance with sharing planning to activate the parents' } \\
\text { collaboration in making plans. }\end{array}$ & 4.21 & 0.828 & Very high \\
\hline 4 & Planning to how to provide the kindergarten with necessary facilities. & 4.11 & 0.989 & High \\
\hline 5 & Planning to how to run meetings. & 3.88 & 0.978 & High \\
\hline 6 & $\begin{array}{l}\text { Being familiar with the methods of activating the teachers' } \\
\text { participation in setting plans. }\end{array}$ & 3.84 & 0.845 & High \\
\hline 7 & Training teachers on how to participate in decision-making. & 3.78 & 1.069 & High \\
\hline 8 & Training on how to work out the plan of parents' meetings. & 4.07 & 1.065 & High \\
\hline 9 & How to plan the teachers' schedules. & 3.90 & 0.953 & High \\
\hline 10 & $\begin{array}{l}\text { Being familiar with the technique of planning the employees' } \\
\text { schedules. }\end{array}$ & 4.16 & 0.880 & High \\
\hline 11 & Planning the kindergartens' activities. & 4.31 & 0.796 & Very high \\
\hline 12 & $\begin{array}{l}\text { Being familiar with the needed skills for putting the plan that } \\
\text { guarantees the kids' safety. }\end{array}$ & 4.11 & 0.895 & High \\
\hline \multirow[t]{2}{*}{13} & Ability to run periodical debates with teachers. & 3.86 & 0.895 & High \\
\hline & The domain as a whole. & 4.05 & 0.650 & High \\
\hline
\end{tabular}

With regard to the second domain, Table 4 shows the means and standard deviation for the items of the organizing domain. As shown, the first item (organizing halls in a way that accomplishes the kindergarten's educational aims), the $9^{\text {th }}$ item (familiarity with the way of organizing the kids' records), and the $11^{\text {th }}$ item (distributing time among the work fields in kindergarten) had the highest mean values. However, the rest of the domain items had a high degree of demand, and their means range (3.95-4.19). It is noted that the difference between the degrees of demand for this domain items was very little, and that indicates the importance of these items, and that the principals urgently need to be trained on them. That is the principals greatly realize the requirements of their leading position so as to practice their professional and technical duties properly, in addition to their certain desire for advancing and developing their performance skills to satisfy these requirements.

Table 4. Means and standard deviations for the items of the organizing domain

\begin{tabular}{|c|c|c|c|c|}
\hline No. & Item & $\begin{array}{c}\text { Mean } \\
*\end{array}$ & SD & $\begin{array}{c}\text { Demand } \\
\text { Degree }\end{array}$ \\
\hline 1 & $\begin{array}{l}\text { Organizing halls in a way that accomplishes the kindergarten's } \\
\text { educational aims. }\end{array}$ & 4.47 & 0.722 & Very high \\
\hline 2 & $\begin{array}{l}\text { Familiarity with how to organize the kindergarten's record of funds \& } \\
\text { expenses. }\end{array}$ & 4.01 & 0.794 & High \\
\hline 3 & Acquaintance with the needed skills for organizing the kids' meetings. & 4.07 & 0.805 & High \\
\hline 4 & Distributing the programs of the kindergarten's educational activities. & 4.23 & 0.818 & Very high \\
\hline 5 & $\begin{array}{l}\text { Delegating duties and responsibilities among the kindergarten's } \\
\text { teachers. }\end{array}$ & 4.19 & 0.824 & High \\
\hline 6 & Being trained on how to organize halls for dividing kids. & 3.95 & 0.770 & High \\
\hline 7 & Being trained on preparation of new kids arrangements. & 4.06 & 0.845 & High \\
\hline
\end{tabular}


8 Familiarity with the way of organizing the record of the administration meetings.

$4.08 \quad 0.876 \quad$ High

4.36 $0.942 \quad$ Very high

9 Familiarity with the way of organizing the kids' records.

Familiarity with the way of organizing the record of input and output in the kindergarten.

11 Distributing time among the work fields in kindergarten.

$4.04 \quad 0.744 \quad$ High

Being trained on how to organize the record of furniture, facilities and teaching techniques.

13 Being familiar with the way of organizing the Ministry's and Directorate's decisions.

14 Familiarity with the way of organizing the record of supervisors' and inspectors' visits.

4.26 $0.807 \quad$ Very high

$4.04 \quad 0.741 \quad$ High

$3.91 \quad 0.838 \quad$ High

$3.99 \quad 0.980 \quad$ High

15

Familiarity with the way of organizing the record of teachers' meetings.

16 Familiarity with the way of organizing the record of parents' meetings.

17 Organizing the dates of stages' activities.

$4.04 \quad 1.004 \quad$ High

$3.96 \quad 1.014 \quad$ High

$3.99 \quad 1.094 \quad$ High

18

Familiarity with the way of organizing the record of employees' attendance.

4.01 $1.002 \quad$ High

The domain as a whole.

$4.14 \quad 0.560 \quad$ High

With regard to the third domain, Table 5 shows the items for the guiding domain. As shown in the table, all items had high training needs for principals. The $2^{\text {nd }}$ item (guiding teachers towards progressing their kids' creative skills) got a mean of (4.18), whereas the rest of the domain items got means that ranged (3.84-4.06). It is noted that the difference between the degrees of demand for this domain items was little, and that indicates the importance of these items, and that the principals urgently need to be trained on them. That is the principals greatly realize the importance of utilizing the creativity skills for conducting their duties properly, in addition to their certain desire for progressing their performance skills to satisfy these requirements. That need could be ascribed to the idea that the schools' principals have become, in the presence of creativity and its utilization, obliged to handle it while practicing their administrative chores particularly that this domain is always updating and changing due to the changes and developments of new concepts especially those concerned with the kindergarten stage.

Table 5. Means and standard deviations for the items of the guiding domain

\begin{tabular}{|c|c|c|c|c|}
\hline No. & Item & $\begin{array}{c}\text { Mean } \\
*\end{array}$ & SD & $\begin{array}{l}\text { Demand } \\
\text { Degree }\end{array}$ \\
\hline 1 & How to guide teachers to know and progress their kids' interests. & 3.88 & 0.824 & High \\
\hline 2 & Guiding teachers towards progressing their kids' creative skills. & 4.18 & 0.927 & High \\
\hline 3 & $\begin{array}{l}\text { Being aware of the teachers' guidance methods for implementing the } \\
\text { daily plans and programs. }\end{array}$ & 4.06 & 0.846 & High \\
\hline 4 & Guiding teachers towards reinforcing relationships with parents. & 3.84 & 0.909 & High \\
\hline 5 & $\begin{array}{l}\text { Being trained on how to guide teachers towards reinforcing the spirit of } \\
\text { cooperation and team work. }\end{array}$ & 3.94 & 0.953 & High \\
\hline 6 & Following up the teachers' and employees' work. & 4.05 & 0.872 & High \\
\hline 7 & $\begin{array}{l}\text { Educating teachers for the necessity for the interactive linking of } \\
\text { curriculum with the local community needs. }\end{array}$ & 4.03 & 0.712 & High \\
\hline 8 & How to guide and help new teachers to be able to cope with work. & 4.16 & 0.674 & High \\
\hline 9 & How to guide teachers to take individual differences into consideration. & 4.12 & 0.815 & High \\
\hline
\end{tabular}




\begin{tabular}{lllll}
\hline 10 & $\begin{array}{l}\text { Being aware of teachers' guidance techniques for following kids in } \\
\text { yards and activity rooms. }\end{array}$ & 4.18 & 0.805 & High \\
11 & Following up the teachers' attendance and absence. & 4.09 & 0.981 & High \\
12 & Following up the work procedures in kindergarten. & 3.80 & 1.005 & High \\
13 & Guiding teachers towards achieving professional development. & 4.02 & 0.872 & High \\
14 & Following up the kids' daily check-up schedules. & 3.91 & 0.873 & High \\
15 & $\begin{array}{l}\text { Familiarity with teachers' guidance techniques for avoiding the work } \\
\text { troubles. }\end{array}$ & 4.14 & 0.849 & High \\
16 & How to guide teachers to know and progress their kids' interests & 4.16 & 0.636 & High \\
& The domain as a whole. & 3.99 & 0.685 & High \\
\hline
\end{tabular}

With regard to the fourth domain, Table 6 shows the means and standard deviations for the guiding domain. As shown in the table, all domain items are considered necessary training needs for the principals' of governmental schools having kindergartens' in a high degree. The $13^{\text {th }}$ item (Being trained on how parents could take part in the evaluation process) got a mean of (4.14), whereas the rest of the domain items got means that ranged (3.58-4.11). It is noted that the difference between the degrees of demand for this domain items was little, and that indicates the importance of these items, and that the principals urgently need to be trained on them. That is the principals greatly realize the importance of being acquainted with way of how parents could take part in the evaluation process in the kindergarten so as to ascend with the kids' cultural and scientific levels, as well as educating teachers of the necessity of linking the parents' participation with the kid's growth process within all aspects. That could be achieved through the cooperation with the surrounding environment and who is concerned with the kindergarten. That need could be ascribed to the idea that the schools' principals feel that the parents' participation satisfy the kids' ambitions and cognitive levels, in addition to the fact that it is necessary for the kids' psychology.

Table 6. Means and standard deviations for the items of the assessing domain

\begin{tabular}{lllll}
\hline No. & Item & $\begin{array}{c}\text { Mean } \\
*\end{array}$ & SD & $\begin{array}{c}\text { Demand } \\
\text { Degree }\end{array}$ \\
\hline 1 & $\begin{array}{l}\text { Being trained on how to form monthly reports regarding work } \\
\text { procedure in the kindergarten. }\end{array}$ & 3.81 & 0.909 & High \\
2 & $\begin{array}{l}\text { Being trained on evaluating activities execution, inside the activity } \\
\text { room and outside it. }\end{array}$ & 3.95 & 0.825 & High \\
3 & Being aware of the needed skills for evaluating each kid's progress. & 3.58 & 1.009 & High \\
4 & Ability to evaluate the teacher's performance. & 4.10 & 0.917 & High \\
5 & Checking up the validity of the kindergarten's facilities. & 3.86 & 0.955 & High \\
6 & Being trained on how teachers could take part in evaluating curriculum. & 4.05 & 0.876 & High \\
7 & Being aware of solving momentary problems methods. & 4.14 & 0.825 & High \\
8 & Being trained on evaluating the curriculum execution. & 4.13 & 0.815 & High \\
9 & Being trained on how teachers could take part in kids' evaluation & 4.12 & 0.805 & High \\
& process. & 4.11 & 0.981 & High \\
10 & Ability to evaluate the employees' performance. & 4.05 & 0.741 & High \\
11 & Following up the daily-check up employees' schedules. & 4.11 & 1.005 & High \\
12 & Following up the daily-check up teachers' schedules. & 4.14 & 0.825 & High \\
13 & Being trained on how parents could take part in the evaluation process. & 4.09 & 0.784 & High \\
14 & Being aware of techniques of accomplishing the kindergarten's aims. & 3.89 & 0.733 & High \\
\hline
\end{tabular}




\subsection{Results and Discussion Pertain to the Second Objective}

The second research objective was to determine if significant differences exist in the training needs of governmental schools' principals based on the demographic variables of academic qualifications, experience, and training workshops. To answer this objective, t-test for independent samples and NOVA statistical testing were used. The academic qualifications variable had two levels (Bachelor and higher education) and t-test was the test used. Table 7 shows that there were no statistically significant differences for all of the study domains between the governmental schools' principals' perceptions who have B.A degree, and the principals who hold M.A. degree or $\mathrm{PhD}$ (higher education). This result asserts the governmental schools' principals' consensus regardless of their qualification on the necessity of being trained on all the skills included in the four domains. This result seems different from the results of Al-Ajaj's study (2001), but it is similar to the result of Al-Ghamedy's study (2004).

Table 7. T-test analysis for the academic qualification variable

\begin{tabular}{lcccccccc}
\hline \multirow{2}{*}{ Domain } & \multicolumn{9}{c}{ Academic qualification } & & & \\
\cline { 2 - 5 } & \multicolumn{2}{c}{ B.A. } & \multicolumn{3}{c}{ Higher Education } & Degrees of freedom & T-value & p-value \\
\cline { 2 - 5 } & Mean & SD & Mean & SD & & & \\
\hline Planning & 4.04 & 0.626 & 4.19 & 0.923 & 100 & 0.585 & 0.576 \\
Organizing & 3.96 & 0.678 & 4.43 & 0.613 & 100 & 1.204 & 0.231 \\
Guidance & 4.12 & 0.552 & 4.39 & 0.689 & 100 & 1.402 & 0.164 \\
Assessment & 3.86 & 0.729 & 4.23 & 0.745 & 100 & 1.373 & 0.173 \\
Entire Tool & 4.05 & 0.538 & 4.32 & 0.681 & 100 & 1.272 & 0.206 \\
\hline
\end{tabular}

The experience variable had three levels, therefore ANOVA analysis was utilized. It is clear in Table 8 that there were differences between the means for some domains according to the variable of experience. ANOVA results are presented in Table 9. It is clear in Table 9 that there are no statistically significant differences for all of the study domains between the principals' perceptions within the 3 levels (less than $5 \mathrm{yrs}$, (5-10) yrs, more than 10 yrs). This result asserts the principals' consensus, regardless of their years of experience, on the necessity of being trained on all the skills included in the four domains, and that their need for these skills was very high for all levels of experience. This study agrees with the results of Al-Ghamedy's (2004) study.

Table 8. Means and standard deviation for the variable experience

\begin{tabular}{lcccccc}
\hline \multirow{2}{*}{ Domain } & \multicolumn{6}{c}{ Years of Experience } \\
\cline { 2 - 7 } & \multicolumn{1}{c}{ Less than 5 yrs. } & \multicolumn{2}{c}{$(5-10)$ yrs. } & \multicolumn{3}{c}{ More than 10 yrs. } \\
\cline { 2 - 7 } & Mean & SD & Mean & SD & Mean & SD \\
\hline Planning & 3.96 & 0.671 & 4.12 & 0.577 & 4.05 & 0.650 \\
Organizing & 4.09 & 0.545 & 4.16 & 0.563 & 4.14 & 0.560 \\
Guidance & 3.97 & 0.633 & 3.96 & 0.784 & 3.99 & 0.685 \\
Assessment & 3.71 & 0.742 & 3.96 & 0.833 & 3.89 & 0.733 \\
Entire Tool & 3.99 & 0.562 & 4.11 & 0.568 & 4.07 & 0.551 \\
\hline
\end{tabular}

Table 9. ANOVA analysis for the experience variable

\begin{tabular}{lcccccc}
\hline \multirow{2}{*}{ Domain } & Source of Variance & Sum of Squares & DF & Mean of Squares & F-value & Level of Significance \\
\hline \multirow{2}{*}{ Planning } & Between groups & 58.403 & 2 & 29.202 & 0.388 & 0.679 \\
\multirow{2}{*}{ Organizing } & Inside groups & 7441.763 & 99 & 75.169 & & 0.802 \\
\hline
\end{tabular}




\begin{tabular}{lcccccc}
\hline \multirow{4}{*}{ Guidance } & Inside groups & 5604.198 & 99 & 56.608 & & \\
& Between groups & 3.652 & 2 & 1.826 & 0.104 & 0.901 \\
& Inside groups & 1732.554 & 99 & 17.501 & & \\
\multirow{2}{*}{ Assessment } & Between groups & 52.137 & 2 & 26.068 & \multirow{2}{*}{0.329} & 0.269 \\
& Inside groups & 1941.824 & 99 & 19.614 & & \multirow{2}{*}{0.448} \\
\hline \multirow{2}{*}{ Entire Tool } & Between groups & 1761.810 & 2 & 880.905 & 0.89 & \\
& Inside groups & 1077793.01 & 99 & 1088.818 & & \\
\hline
\end{tabular}

The third variable investigated in this study was training workshops. Table 10 shows the means and standard deviations for the variable training workshops. It is clear in the table that there were apparent differences between the means for some domains and to identify the statistical significance of these differences, ANOVA was used and the results are shown in Table 11.

Table 10. Means and standard deviation for the variable training workshops

\begin{tabular}{lcccccc}
\hline \multirow{2}{*}{ Domain } & \multicolumn{9}{c}{ Levels of training } \\
\cline { 2 - 7 } & \multicolumn{2}{c}{ Less than 3 courses } & \multicolumn{2}{c}{$(3-5)$ courses } & \multicolumn{2}{c}{ More than 5 courses } \\
\cline { 2 - 7 } & Mean & SD & Mean & SD & Mean & SD \\
\hline Planning & 3.92 & 0.757 & 3.85 & 0.642 & 4.05 & 0.650 \\
Organizing & 3.96 & 0.666 & 3.91 & 0.579 & 4.14 & 0.560 \\
Guidance & 3.88 & 0.636 & 3.76 & 0.735 & 4.15 & 0.639 \\
Assessment & 3.79 & 0.648 & 3.66 & 0.769 & 4.04 & 0.709 \\
Entire Tool & 3.90 & 0.663 & 3.88 & 0.546 & 4.22 & 0.478 \\
\hline
\end{tabular}

Table 11. ANOVA analysis for the training workshop variable

\begin{tabular}{|c|c|c|c|c|c|c|}
\hline Domain & Source of Variance & Sum of Squares & $\mathrm{DF}$ & Mean of Squares & F-value & Level of Significance \\
\hline \multirow{2}{*}{ Planning } & Between groups & 461.196 & 2 & 230.598 & \multirow{2}{*}{3.243} & \multirow{2}{*}{0.043} \\
\hline & Inside groups & 7038.970 & 99 & 71.101 & & \\
\hline \multirow{2}{*}{ Organizing } & Between groups & 675.631 & 2 & 337.816 & \multirow{2}{*}{6.651} & \multirow{2}{*}{0.002} \\
\hline & Inside groups & 4953.545 & 99 & 50.036 & & \\
\hline \multirow{2}{*}{ Guidance } & Between groups & 122.445 & 2 & 61.222 & \multirow{2}{*}{3.756} & \multirow{2}{*}{0.027} \\
\hline & Inside groups & 1613.761 & 99 & 16.301 & & \\
\hline \multirow{2}{*}{ Assessment } & Between groups & 107.666 & 2 & 53.833 & \multirow{2}{*}{2.825} & \multirow{2}{*}{0.064} \\
\hline & Inside groups & 1886.295 & 99 & 19.053 & & \\
\hline \multirow{2}{*}{ Entire Tool } & Between groups & 11408.332 & 2 & 5704.166 & \multirow{2}{*}{5.754} & \multirow{2}{*}{0.004} \\
\hline & Inside groups & 98146.492 & 99 & 991.379 & & \\
\hline
\end{tabular}

It is clear in Table 11 the existence of statistically significant differences for all of the study domains (planning, organizing, guidance and assessment) between the principals' points of view within the 3 levels (Less than 3 courses, (3-5) courses, and More than 5 courses) for the benefit of the principals who were exposed to more courses. This result asserts the necessity of continuing training on all skills included within the 3 domains, and it is compatible with the result of Al-Ghamedy's (2004) study as well as Al-Zmeily's (2005) study. The table also indicates that there were no statistically significant differences for the assessment domain between the principals' points of view within the 3 levels (Less than 3 courses, (3-5) courses, and More than 5 courses). This result asserts the principals' consensus, regardless of their training courses, on the necessity of being trained on all the skills included in this domain, and that could be ascribed to their interest in recognizing the assessment methods 
during the kindergarten stage and analyzing them so as to be linked to the kids' needs.

\section{Conclusions}

Based on the study results, some conclusions were attained, and the following are the most important:

1) The demands of the governmental schools' principals having kindergartens in Mafraq have been identified and ordered according to their importance and priority degree in accordance to the following domains: planning, organizing, guiding and assessment.

2) There were no statistically significant differences for all of the study domains according to the academic qualification between the schools' principals' perception who hold B.A. degree and the principals who hold M.A. or $\mathrm{Ph} \mathrm{D}$ degree (Higher Education).

3) There were no statistically significant differences for all of the study domains according to the years of experience between the schools' principals' points of view for all levels (less than 5 yrs, 5-10 yrs, more than 10 yrs).

4) There were statistically significant differences for the study domains (planning, organizing, guiding) according to the number of training courses between the schools' principals' perceptions for all levels (less than 3 courses, 3-5 courses, more than 5 courses) for the benefit of those who took more training courses.

5) There were no statistically significant differences for the study domain (assessment) according to the number of training courses between the schools' principals' perceptions for all levels (less than 5 yrs, 5-10 yrs, more than 10 yrs).

\section{Recommendations}

Based on this study results, the researcher recommends the following:

1) Designing training workshops for the principals of governmental schools having kindergartens in light of the training demands mentioned in this study and according to the four domains, taking into consideration the importance and priority these principals see in their need of training.

2) Ongoing training for the principals of governmental schools having kindergartens within the study domains, regardless of their qualifications or experiences.

3) Increasing the number of training courses and programs for the schools principals within the study domains mentioned earlier.

4) Conducting evaluative studies for measuring the impact of the training courses that are based on the principals' demands on their performance level.

5) Because the requirements to become a principal in many countries worldwide are contingent on teaching qualification and teaching experience, specific and detailed preparation training package for principals should be developed (Bush, Kiggundu, \& Moorosi, 2011).

\section{Implications for Higher Education}

The present study investigated training needs of governmental school principals hosting kindergarten classes. The results indicated that principals have high training needs in four areas including planning, designing, assessment, and guidance. Higher education in Jordan can play an important role in providing principals with all of their training needs since they are equipped with the needed infrastructure to conduct such training. Specifically, two colleges (college of educational sciences and college of childhood) can host training workshops and seminars on a regular basis to better equip principals with the necessary skills in the areas of dealing with kindergartens. Moreover, ministry of higher education cans partnership with ministry of education to provide principals with special courses in planning, organizing, assessment, and guidance. Further, the pre-service training programs for teachers (future principals) that is utilized by higher education institutions can be revised to better emphasize planning, organizing, assessment, and guidance, which is partially neglected in such training programs for pre-service teachers. Finally, it is hoped that higher education institutions in Jordan will take proactive steps to provide national schools with teachers and principals who are skilled in all areas of conducting work successfully.

Finally, it is important to emphasize the concept of the global principal who can work and succeed in many educational systems especially in the western parts of the world. To elaborate, in today's changing world all educational systems should prepare principals and train them on all aspects of school management and leadership based on a world view. This will help to retain and have a surplus of world class principals who can be exchanged between countries. 


\section{References}

Abdeen, M. (2001). The modern school management. Amman, Jordan: Dar Al-Shorouq for publishing \& distribution.

Abu-Sheikha, N. (2000). Managing human resources. Amman, Jordan: Dar Al-Safa for publishing \& distribution.

Al-Ajaj, F. (2001). Identifying the training demands of governmental schools' principals in Qrayat from their own Point of View (MEd dissertation, Yarmouk University, Jordan).

Al-Mekhlafi, M., \& Abu-Bakr, M. (1997). The principals of educational management. Sana'a, Yemen: Printers of School Book.

Al-Rawi, R. F. et al. (2000). The educational management-Its theories \& applications in teaching kindergarten. Kuwait: Al-Falah Library.

Al-Sane', A. A. (1995). Measuring the affectivity of the school principal performance of his expected roles. College of Education Journal, 12, 23-45.

Al-Shmeiry, M. (1995). Estimation of training demands of secondary schools' principals and assistants in the cities of Ta'ez \& Sana'a in Yemen from their own point of view (Unpublished master thesis). Jordan: Yarmouk University.

Al-Ta'any, H. (2002). Training: its concept \& efficacy. Amman, Jordan: Dar Al-Shorouq for publishing \& distribution.

Bush, T., Kiggundu, E., \& Moorosi, P. (2011). Preparing new principals in South Africa: The ACE School Leadership Programme1. South African Journal of Education, 31, 31-43.

Carpenter, J. (2001). The school principal \& his role in developing learning. Miami, Florida: International Florida Press.

Diab, I. (2001). The school management. Alexandria, Egypt: New University press.

Fahmi, S. E., \& Hussain, M. (1993). Developing the school management in the Arab Gulf States. Riyadh, Saudi Arabia: the Education Office for the Gulf States.

Falouqi, H. (2003). Training during work: A study of some professional development aspects. Benghazi, Libya: Republic press.

Hanna, S. (2003). The Training Demands of Kindergartens' Female Employees in Jordan (Unpublished master thesis). Jordan: The Hashemite University.

Jaradat, S. (1991). The Training Demands of Governmental Basic Schools' Principals in Irbid (Unpublished master thesis). Jordan: Yarmouk University.

Kashwa, A. (1999). The obstacles of training the principals of basic schools in Yemen (Unpublished master thesis). Sudan: Al-Jazeera University.

Mathibe, I. (2007). The professional development of school principals. South African Journal of Education, 27(3), 523-540.

Mestry. R., \& Singh, P. (2007). Continuing professional development for principals: A South African perspective. South African Journal of Education, 27(3), 477-490.

Mousa, A. A. (1994). In-service training. Riyadh, KSA: King Fahd National Library.

Mustafa, A. (2010). Managing development of kindergarten-global Arabian models. Cairo: Publishing Dar for Universities.

Nashwan, J. (1991). Management \& educational supervision between theory and practice. Amman, Jordan: Dar Al-Furqan for Publishing \& Distribution.

Ngidi, D., \& Qwabe, J. (2006). The partnership of parents, educators and principals in creating a culture of teaching and learning in schools. South African Journal of Education, 26(4), 529-539.

Prew. M. (2007). Successful principals: Why some principals succeed and others struggle when faced with innovation and transformation. South African Journal of Education, 27(3), 447-462.

Qanadeily, J. (2003). Remote training \& education using electronic management. The $2^{\text {nd }}$ administrator for management \& new global changes, Riyadh. 
Raffa, S. (1993). Identifying the training demands of secondary stage science teachers in the South-West of Saudi Arabia. Magazine of Arab Gulf Message, 45, 53-80.

Sunkur, S. (1980). Methods of assessing teachers. Damascus, Syria: Ittihad Printers.

Zaghloul, E., Ahmad, R., \& Ahmad, A. (2005). The organizational culture \& the efficacy of Egyptian school performance. Educational Management, 17, 13-20.

\section{Copyrights}

Copyright for this article is retained by the author(s), with first publication rights granted to the journal.

This is an open-access article distributed under the terms and conditions of the Creative Commons Attribution license (http://creativecommons.org/licenses/by/3.0/). 